\title{
TAFSIR ILMU TENTANG MENGELOLA WAKTU
}

\author{
M. Rais Umam Bisri \\ Mahasiswa Pascasarjana S2 MPI UIN SGD Bandung \\ e-mail: raisumambisri@gmail.com
}

\begin{abstract}
ABSTRAK
Dalam ajaran Islam, Allah memerintahkan hamba-Nya untu memanfaatkan waktu dengan sebaikbaiknya, karena waktu merupakan hal yang sangat urgen sehingga memanfaatkan waktu merupakan amanat Allah kepada makhluk-Nya. Karena demikian urgenya peranan waktu, maka Allah berkalikali bersumpah dengan menggunakan kata yang menunjukkan waktu-waktu tertentu. Al-Qur'an juga menggunakan term yang menunjukkan waktu yang berbeda-beda. Didalam al-Qur ${ }^{\text {ee } a n}$ pengungkapan waktu terdapat dua bentuk, yaitu term yang menunjukkan durasi yang jelas batasanya seperti ghada>h, 'ashr, bukrah, ashi>la, 'asyiyya', 'isya', layl, naha $>r$, yawm, syahr, 'am, sanah.sedangkan term yang menunjukkan durasi yang tidak jelas batasanya seperti waqt, dahr,

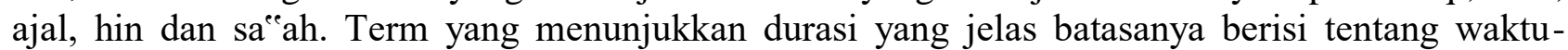
waktu tertentu atau momentum kebajikan, waktu untuk beribadah dan juga menunjukkan perjalanan waktu atau perputaran matahari dan bulan dimana semua kejadian tersebut dapat dikatahui oleh manusia. Sedangkan term yang menunjukkan durasi yang tidak jelas batasanya berisi tentang keniscayaan, kebangkitan, penguasaan ruh dan maut, penentuan kematian, dan kebangkitan dan hari kiamat dimana hal tersebut tidak dapat diketahui oleh siapapun, seperti dahr digunakan untuk saat berkepanjangan yang dilalui alam raya dalam kehidupan dunia ini yaitu sejak diciptakan-Nya sampai punahnya alam, ajal menunjukkan waktu berakhirnya sesuatu seperti berakhirnya usia manusia, sa ${ }^{e e}$ ah menunjukkan akhir masa kehidupan duniawi serta kepunahan alam dan lain-lain.
\end{abstract}

Kata Kunci: Tafsir Ilmu, Mengelola, Waktu

\section{ABSTRACT}

In the teachings of Islam, Allah instructs His servants to make the best use of time, because time is very important, so taking advantage of time is Allah's mandate to His creatures. Because of the urgency of the role of time, Allah repeatedly swore by using words denoting certain times. AlQur'an also uses terms which indicate different times. In the Koran, the disclosure of time has two forms, namely terms which indicate a clear duration of boundaries such as ghada> $h$, 'ashr, bukrah, ashi> la,' asyiyya ',' isya ', layl, naha> r, yawm, syahr, 'am, sanah. while the terms which indicate the duration with no clear boundaries such as waqt, dahr, ajal, hin and sa'ah. The term which shows the duration with a clear boundary contains certain times or momentum of virtue, time to worship and also shows the time travel or rotation of the sun and moon where all these events can be known by humans. Meanwhile, the term which shows the duration with no clear boundaries contains the inevitability, resurrection, control of spirit and death, the determination of death, and resurrection and the Day of Judgment where it cannot be known by anyone, such as dahr is used for prolonged moments that the universe passes through in the life of the world. this is from the time He was created to the extinction of nature, death indicates the end time for something such as the end of human life, sa'ah indicates the end of the worldly life and the extinction of nature and so on.

Keywords: Knowledge Interpretation, Managing, Time

\section{PENDAHULUAN}

Manusia tidak dapat melepaskan diri dari waktu dan tempat. Mereka mengenal masa lalu, kini dan masa depan. Kesadaran manusia tentang waktu berhubungan dengan bulan dan matahari dari segi perjalananya (malam saat terbenam dan siang saat terbit). 
Waktu adalah seluruh rangkaian saat yang telah berlalu, sekarang, maupun yang akan datang.

Memanfaatkan waktu merupakan amanat Allah kepada makhluknya. Bahkan, manusia dituntut untuk mengisi waktu dengan berbagai amal dan mempergunakan potensinya, karena manusia diturunkan ke dunia ini adalah untuk beramal. Agama melarang mempergunakan waktu dengan main-main atau mengabaikan yang lebih penting. Nampaknya waktu dan amal tidak dapat dipisahkan. Waktu adalah untuk beramal dan beramal adalah untuk mengisi waktu. Amal akan berguna bila dilaksanakan sesuai dengan waktunya, sebaliknya waktu akan bermakna bila diisi dengan amal (Fahmi Idris, 1999).

Sekarang ini, banyak ditemui orang yang suka menyalahkan waktu atau setidaknya mengkambing hitamkan waktu ketika mengalami kegagalan. Islam sebenarnya tidak pernah mengenal waktu sial atau waktu untung. Sial dan untung sangat ditentukan oleh baik dan tidaknya usaha seseorang, karena waktu bersifat netral dan waktu tidak pernah berpihak pada siapapun (Fahmi Idris, 1999).

Demikian besar peranan waktu sehingga Allah Swt berkali-kali bersumpah dengan menggunakan kata yang menunjukkan waktuwaktu tertentu seperti wa al- layl (demi malam), wa al-nahār (demi waktu siang), wa al-subh (demi waktu subuh), wa al-fajr (demi waktu fajar), wa al-dhuha (demi waktu dhuha), wa al-'ashr (demi waktu ashar) (Yusuf al-Qardhowi, 2005). Untuk menegaskan pentingnya waktu dan keagungan nilainya, seperti yang terdapat dalam al-Qur'an Surah Al-Lail [92]: 1-2, AlFajr [89]: 1-2, Adh-Dhuha [93]:1-2, Al-'Ashr [103]: 1-3, dan lain-lain.

\section{وقت Kata Waqt berasal dari akar kata}

yang terdiri dari tiga huruf, yaitu: wau, qaf, dan ta, yang artinya menentukan atau menetapkan waktu. Kata waktu adalah mufrad, bentuk jamaenya adalah auqatun yang mempunyai arti waktu (Ahmad Warson, 1997). Dalam Mu'jam al-Mufahras li al-
Fadz\} al-Qur'an kata waqt disebut 13 kali. Derivasinya dalam berbagai bentuk, isim (kata benda) dibagi menjadi 12 bentuk, seperti dalam surat Al-Hijr [15]: 38, Sad [38]: 81, Al-A'raf [7]: 187, Al-A'raf [7]: 142, Asy-Syu'ara' [26]: 38, Al-Waqi'ah [56]: 50, Annabā' [78]: 17, Al-A'raf [7]: 143, AlA'raf [7]: 155, Al-Baqarah [2]: 189, An-Nisa' [4]: 103, Ad-Dukhān [44]: 40. Dan fi'il Mādi (kata kerja yang munjukkan waktu lampau) terdapat 1 bentuk, seperti dalam surat AlMursalat [77]: 11. (M. Fuad Abdul Baqi, 1991)

Al-Qur'an menggunakan beberapa term yang menunjukkan waktu, seperti ghadah, 'ashr, bukrah, ashila, 'asyiyya', 'isya', layl, nahar, yawm, syahr, 'am, sanah, waqt, dahr, ajal, 'ashr, sa'ah, hin. Kata waqt dalam alQur'an diulang 13 kali, (M. Fuad Abdul Baqi, 1991) waqt digunakan dalam batas akhir kesempatan atau peluang untuk menyelesaikan suatu peristiwa, misalnya:

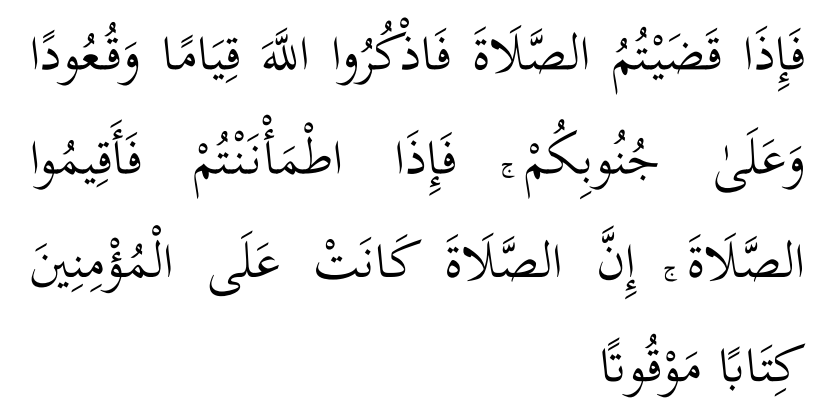

"Maka apabila kamu telah menyelesaaikan shalat (Mu), ingatlah Allah diwaktu berdiri, diwaktu duduk dan diwaktu berbaring. Kemudian apabila kamu telah merasa aman, Maka dirikanlah shalat itu (sebagaimana biasa). Sesungguhnya shalat itu adalah fardhu yang ditentukan waktunya atas orangorang yang beriman". (Q.S. Al-Nisa' [4]: 103)

Allah memberikan pesan di atas bahwa dzikir setelah shalat dapat dilakukan dengan cara apapun dan bagaimanapun keadaanya. Dalam keadaan normal dilakukan dengan duduk, dalam keadaan gawat dilakukan dengan keadaan yang memungkinkan, bahwa setiap saat diwaktu berdiri, waktu duduk, dan waktu berbaring. Kemudian, shalat apabila dalam keadaaan normal harus dilakukan dengan khusyu' memenuhi syarat rukunya 
serta memenuhi sunnah dan waktu-waktunya yang telah ditentukan. Kata waqt memberikan kesan tentang keharusan adanya pembagian teknis mengenai masa yang dialami (seperti detik, menit, jam, hari, minggu, bulan, tahun dan seterusnya), dan sekaligus keharusan untuk menyelesaikan pekerjaan dalam waktuwaktu tersebut, dan bukanya membiarkanya berlalu hampa (Quraish Shihab, 2000). Dan masih banyak lagi kata atau istilah-istilah yang lain dalam al-Quran yang diulang berkali kali tentang waktu. Dari perbedaan term-term di atas, Allah memberikan berbagai macam warna tentang waktu yang penjelasanya secara rinci

Sehingga Al-Qur'an sebagai kitab suci yang dijadikan pedoman umat Islam telah memberikan cara bagaimana menjadi orang yang beruntung. Untuk itu, dibutuhkan kajian yang komprehensif dalam memahami ayat-ayat al-Qur'an dengan pendekatan tafsir tematik.

\section{HASIL DAN PEMBAHASAN}

\section{Konsep Waqt Dalam Al-Qur'an}

Kata Waqt berasal dari akar kata وقت yang terdiri dari tiga huruf, yaitu: wau, qaf, dan ta, yang artinya menentukan atau menetapkan waktu. Kata waktu adalah mufrad, bentuk jama "enya adalah auqatun yang mempunyai arti waktu (Ahmad Warson, 1997). Menurut bahasa, kata waktu diartikan dengan empat makna: (1) seluruh rangkaian saat, yang telah berlalu, sekarang, dan yang akan datang; (2) saat tertentu untuk menyelesaikan sesuatu; (3) kesempatan, tempo, atau peluang; (4) ketika, atau saat terjadinya sesuatu Quraish Shihab, 2000). Sedangkan dalam Mu'jam al-Wasit kata waqt diartikan waktu tertentu sebagai kadar bagi sebuah perkara (Shauqi Daif, 2011). Menurut al- Manāwiy, waqt adalah kadar tertentu dari sebuah waktu atau batasan yang pasti antara dua perkara yang salah satunya telah diketahui dan satunya akan diketahui.149 Sedangkan waqt dalam al-Qur'an digunakan dalam waktu batas akhir kesempatan atau peluang untuk menyelesaikan suatu peristiwa.
Karena itu, seringkali al-Qurean, menggunakanya dalam konteks kadar tertentu dari satu masa. Dalam al- Qur'an, sendiri ayat-ayat tentang waktu yang tersebar dalam berbagai surat dan ayat dalam Mu'jam al-Mufahras li al-Fadz\} al-Qura'n disebut 13 kali. Sebagian ayat tersebut turun di Makkah dan sebagian lainnya turun di Madinah. Kata waqt disebutkan dalam derivasi dan bentuk, yaitu dalam bentuk isim dibagi menjadi 6 bentuk yaitu isim masdar, jer majruir, isim zaman,isim jamae taksir, isim ma erifah dan isim domir. Dalam bentuk fie il terdapat satu bentuk yaitu dalam bentuk fiecil madi.

\section{Kontekstualisasi Ayat Tentang Waqt}

Setelah dipaparkan tentang konsef waqt penulis akan menganalisa kata waqt berdasarkan bentuk-bentuknya serta konteks ayat yang berkaitan dengan kata waqt di dalam al-Qur'an. Berikut dijelaskan beberapa bentuk kata kerja yang diturunkan dari kata waqt. Dalam Mu'jam al-Mufahras li al-Fadz al-Qura'n kata waqt di sebut 13 kali (Abdul Ba'aqi, 1991). yang memuat term tersebut berkisar tentang: dikumpulkanya manusia pada hari kiamat, keadaan zikir setelah shalat dalam keadaan gawat dapat dilakukan dengan cara apapun, dan shalat apabila dalam keadaan normal harus dilakukan dengan khusyue memenuhi syarat rukunnya serta memenuhi sunnah dan waktuwaktunya yang telah ditentukan, waktu tiupan sangkakala yang pertama tanda permulaan hari kiamat, waktu terjadinya hari kiamat yang hanya dapat diketahui oleh Allah Swt, bulan sabit yang merupakan pertanda bagi manusia untuk menentukan waktu perkaraperkara dunia, dan sebagai pertanda untuk melaksanakan ibadah yang tertentu waktunya seperti puasa, berbuka puasa dan khususnya haji, ditetapkan waktunya, tidak dapat dimajukan dan tidak dapat pula diundurkan, juga tidak dapat ditambahi serta tidak dapat dikurangi, hari pengadilan antara orang yang berbuat kebenaran dan orang yang berbuat kebatilan adalah waktu yang sudah dijanjikan untuk mereka semua. Derivasi kata waqt tersebut adalah: 
1) Isim masdar

Kata waktu dalam bentuk isim masdar disebutkan sebanyak 2 kali. Contohnya kata Mawqūtan. Dilihat dari konteksnya, kata Mawqūtan bermakna yang ditentukan waktunya. Hal tersebut dikaitkan dengan shalat apabila dalam keadaan normal harus dilakukan dengan khusyue memenuhi syarat rukunnya serta memenuhi sunnah dan waktuwaktunya yang telah ditentukan. Contoh konteks ayatnya adalah sebagai berikut:

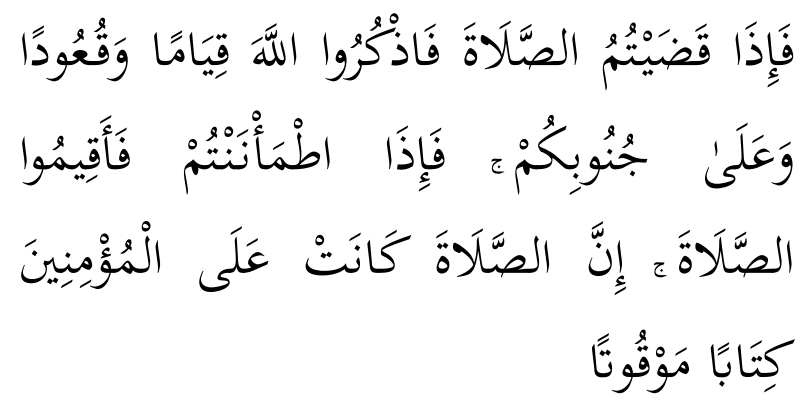

"Selanjutnya, apabila kamu telah menyelesaikan shalat(mu) ingatlah Allah ketika kamu berdiri, pada waktu duduk dan ketika berbaring. Kemudian, apabila kamu telah merasa aman, maka laksanakanlah shalat itu (sebagaimana biasa). Sungguh, shalat itu adalah kewajiban yang ditentukan waktunya atas orang-orang yang beriman”.(Q.S. An-Nisā' [4]: 103).

Allah memberikan pesan di atas bahwa dzikir setelah shalat dapat dilakukan dengan cara apapun dan bagaimanapun keadaanya. Dalam keadaan normal dilakukan dengan duduk, dalam keadaan gawat dilakukan dengan keadaan yang memungkinkan, bahwa setiap saat diwaktu berdiri, waktu duduk, dan waktu berbaring. Kemudian, shalat apabila dalam keadaaan normal harus dilakukan dengan khusyu'e memenuhi syarat rukunya serta memenuhi sunnah dan waktu-waktunya yang telah ditentukan (Quraish Shihab, 2000).

Kata mawqūtan terambil dari kata waqt (waktu).Dari segi bahasa kata ini digunakan dalam arti batas akhir kesempatan atau peluang untuk menyelesaikan suatu pekerjaan.Setiap shalat mempunyai waktu dalam arti ada masa di mana seseorang harus menyelesaikannya.Apabila masa itu berlalu, maka pada dasarnya berlalu juga waktu shalat itu. Ada juga yang memahami kata ini dalam arti kewajiban yang bersinambung dan tidak berubah, sehingga shalat sebagai kitaban mauqutan berarti shalat adalah kewajiban yang tidak berubah, selalu harus dilaksanakan, dan tidak pernah gugur apa pun sebabnya. Tidak ada alasan untuk menyebut bahwa shalat mempunyai waktu-waktu tertentu.Perintah shalat dan aneka ibadah yang ditetapkan setelah mengalami keadaan gawat perlu dilakukan.Islam mengharuskan adanya pembagian tehnis menyangkut masa (dari milenium sampai kedetik).Ini pada gilirannya mengajar umat agar memiliki rencana jangka pendek dan panjang, serta menyelesaikan setiap rencana itu pada waktunya (Quraish Shihab, 2000).

Shalat adalah suatu kewajiban yang sudah ditentukan batas-batas waktu penunainya. Solat lah dengan lengkap dan sempurna tanpa di qashar.Golongan dhohiriyah berpendapat tentang tidak adanya qadha shalat yang terluput, karena qadha ini tidak mencukupi dan tidak sah, sebab shalat itu tidak sah dilakukan kecuali pada waktunya yang telah ditentukan.Apabila waktunya telah habis, tidak ada jalan untuk menunaikan shalat tersebut.Adapun jumhur ulama ${ }^{\text {ee }}$ berpendapat sahnya mengqadha shalat yang terluput, mereka menganggap baik menyegerakan shalat pada awal waktu dan tidak suka mengakhirkanya (Qutb Sayyid, 2000).

\section{2) Jer Majrur}

Kata waktu dalam bentuk jer majrur secara keseluruhan disebutkan sebanyak dua kali. Contohnya kata Limi'qa'tinā. Dilihat dari konteksnya, kata Limi'qa'tinā bermakna pada waktu yang kami tentukan. Makna tersebut dikaitkan dengan perkara yang di tampakkan oleh Allah melainkan hanya sebesar jari kelingking. Contoh konteks ayatnya adalah sebagai berikut :

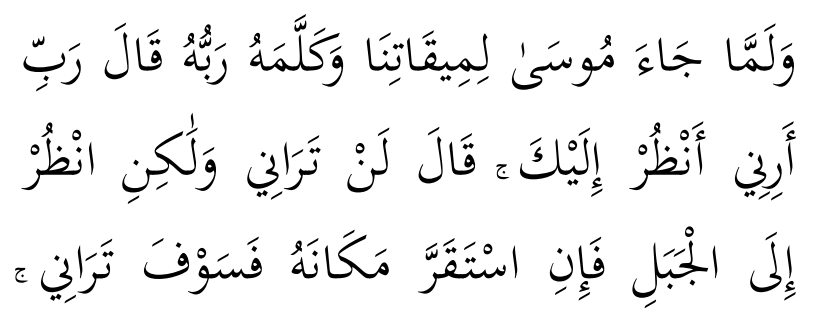




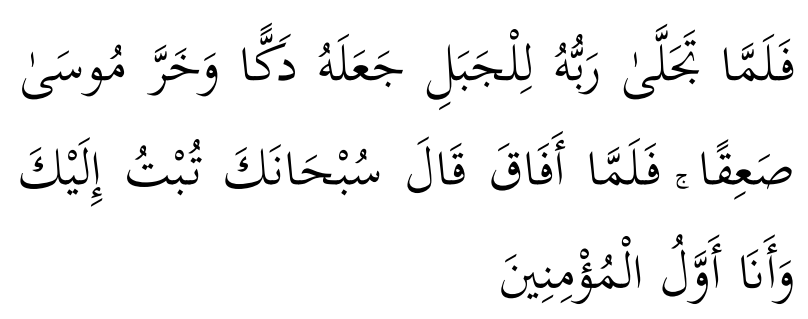

"Dan ketika Musa datang untuk (munajat) pada waktu yang telah Kami Tentukan dan Tuhan telah Berfirman (langsung) kepadanya, (Musa) berkata, "Ya Tuhan-ku, tampakkanlah (diri-Mu) kepadaku agar aku dapat melihat Engkau." (Allah) Berfirman, "Engkau tidak akan (sanggup) melihat-Ku, namun lihatlah ke gunung itu, jika ia tetap di tempatnya (sebagai sediakala) niscaya engkau dapat melihat-Ku." Maka ketika Tuhan-nya Menampakkan (keagungan-Nya) kepada gunung itu, gunung itu hancur luluh dan Musa pun jatuh pingsan. Setelah Musa sadar, dia berkata, "Maha Suci Engkau, aku bertobat kepada Engkau dan aku adalah orang yang pertama-tama beriman". (AlA"raf [7]: 143).

Ketika Nabi Musa as. mendapat anugerah "mendengar kalam Ilahi", yakni kitab Taurat yang akan jadi pimpinan bagi bangsanya, beliau timbul hasrat untuk memperoleh yang lebih dari itu, yakni berbicara dengan tuhan dan melihatnya sekaligus (Ahmad Mustofa, 1989). Bahwa mereka tidak akan beriman sebelum melihat Allah dengan jelas, yakni dengan mata kepala. Tidaklah dapat melihat Allah dengan mata kepala lagi terang-terangan sebagaimana permintaan sebagian umatnya (Quraish Shihab, 2000).

Nabi Musa As. berharap bisa melihatNya dengan satu cara melalui potensi yang Allah anugerahkan kepadanya, sekaligus sesuai dengan keagungan serta kesuciaan Allah swt. walau bukan dengan terangterangan, atau bukan langsung dengan pandangan mata (Quraish Shihab, 2000). Dia yakin, dan tidak ada keraguan sedikitpun, akan tetapi Dia masih meminta hendak melihat Allah. Keinginan melakukan hal tersebut dikarenakan nabi Musa punya keyakinan yang lebih tinggi, yaitu cinta. Sebab cinta itulah maka Allah menunjukkan diri kepada gunung, sehingga gunung tersebut hancur. Ketika melihat kejadian tersebut beliau pingsan seperti orang kena petir. Beliau merasa sangat puas, sebab Allah benar-benar telah menyatakan cinta kepadaNya.

Maksud Nabi Musa as. itu adalah melihat Allah dengan nalarnya. Betapapun dan penampakan apapun yang beliau maksudkan, namun yang jelas adalah permohonan tersebut tidak diperkenankan Allah swt. Tidak seorangpun di dunia ini yang pernah melihat Allah swt. Bagi Siapa yang berkata bahwa Nabi Muhammad saw. melihat Tuhannya, maka dia telah berbohong. Adapun di dunia ini, cukuplah dengan ilmul yaqin dan haqqul yaqin. Adapun ainul yaqin biarlah di akhirat kelak.

M. Quraish Shihab dalam Tafsir'Al-Mis'bah mengutip pendapat AlGhazali dalam bukunya al-Maqshadul-Asna mengatakan bahwa manusia pun tidak dapat melihat dalam arti menjangkau hakikat Allah dengan nalarnya. Ketuhanan adalah sesuatu yang hanya dimiliki Allah, tidak dapat tergambar dalam benak sesuatu yang mengenalnya kecuali Allah atau yang sama dengan-Nya, dan karena tidak ada yang sama dengan-Nya, maka tidak ada yang mengenalnya kecuali Allah (Quraish Shihab, 2000).

\section{3). Isim Zaman}

Kata waktu dalam bentuk isim zaman diulang sebanyak 2 kali. Contohnya adalah Al-waqti. Dilihat dari konteksnya, kata Alwaqti bermakna waktu (hari kiamat). Hal ini dikaitkan dengan waktu tiupan sangkakala pertama adalah tanda permulaan hari kiamat. berikut:

Contoh konteks ayatnya adalah sebagai

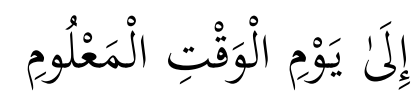

Sampai pada hari yang telah ditentukan waktunya (hari Kiamat). (Q.S. Al-Hijr [15]: 38).

Ayat ini berbicara mengenai kutukan Allah yang diberikan kepada sang iblis dengan sebab keangkuhan dan kedurhakaan yang lahir dari kedengkiannya kepada Adam As.yang menganggap dirinya lebih terhormat 
dan mulia dari adam (Ali Hasan, 2003). Ia tidak memohon ampun, tidak juga meminta ditinggikan derajatnya, tetapi ia berkata dengan tujuan menjerumuskan manusia, serta meminta dipanjangkan usia sampai semua manusia dibangkitkan dari kubur, yaitu hari Kiamat. Akan tetapi setelah itu dia harus mati dan mempertanggung jawabkan atas apa yang ia perbuat (Quraish Shihab, 2000).

Iblis berangan-angan bahwa dirinya akan mangajak anak cucu adam yang ada di bumi ini berbuat maksiat, yang mana dengan berbuat maksiat itu di anggap baik oleh mereka walaupun sebenarnya hal tersebut merupakan sesuatu yang menyesatkan. Kecuali bagi orang-orang yang ikhlas dan taat kepada Allah, setan tidak punya kekuasaan dan kekuatan untuk mengganggu manusia. Permohonan iblis untuk mengganggu manusia dalam perjalananya menuju Allah ini dikabulkan. Dia meminta berbuat demikian sampai dunia ini di tutup.

Iblis minta ditangguhkan usianya sampai hari berbangkit, bukan untuk menyesali perbuatanya dihadapan Allah, bukan untuk bertobat dan menutupi dosa-dosa besarnya. Tetapi, tujuanya untuk melampiaskan balas dendamnya kepada Adam dan anak cucunya yang telah menyebabkan dia terusir dan mendapat laknat. Dia menghubungkan laknat Allah itu kepada Adam dan bukan kepada kesalahannya yang telah menolak perintah Allah.

4). Isim jama ${ }^{e e}$ taksir

Kata waktu dalam bentuk isim jamae taksir disebutkan 1 kali. Contohnya adalah kata Mawāqītu. Dilihat dari konteksnya, kata Mawāqītu bermakna tanda-tanda waktu tertentu. Hal ini dikaitkan dengan bulan sabit yang merupakan pertanda bagi manusia untuk menentukan waktu perkara-perkara dunia, dan sebagai pertanda untuk melaksanakan ibadah yang ditentukan waktunya seperti puasa, berbuka puasa dan khususnya haji. berikut:

Contoh konteks ayatnya adalah sebagai

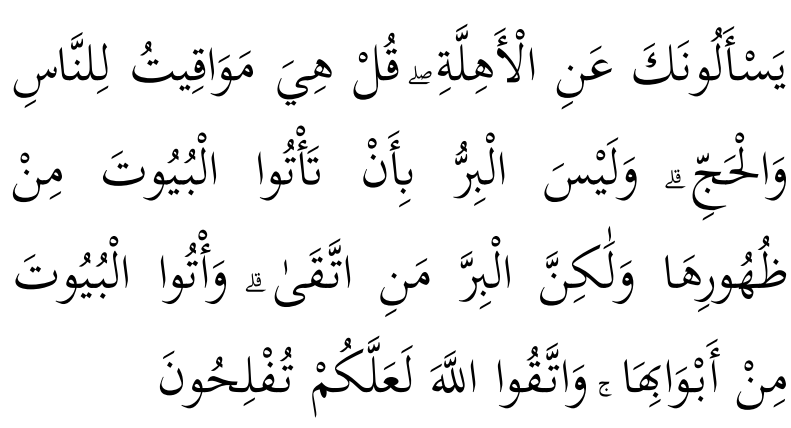

bertanya kepadamu (Muhammad) tentang bulan sabit.Katakanlah, "Itu adalah (penunjuk) waktu bagi manusia dan (ibadah) haji." Dan bukanlah suatu kebajikan memasuki rumah dari atasnya, tetapi kebajikan adalah (kebajikan) orang yang bertakwa. Masukilah rumah-rumah dari pintu-pintunya, dan bertakwalah kepada Allah agar kamu beruntung. (Q.S. AlBaqarah [2]: 189).

Ayat ini berbicara tentang persoalan yang sangat erat dengan pelaksanaan puasa dari segi penentuan waktu, awal dan akhirnya, yaitu soal bulan. Bulan adalah tanda-tanda bagi umat manusia di dalam menentukan urusan dunia mereka. Cukup banyak hukumhukum agama yang dikaitkan dengan kehadiran dan kepergian bulan, seperti puasa, haji, zakat, masa hamil, masa tunggu dan menyusukan bagi wanita dan sebagainya.

Allah menjelaskan tentang bulan sabit dimana terdapat sekian banyak hukum agama yang berkaitan dengannya, diantaranya adalah ibadah haji. Pada masa jahiliyah, orang-orang yang berihram di waktu haji, mereka memasuki rumah dari belakang bukan dari depan. Hal ini ditanyakan pula oleh para sahabat kepada Rasulullah SAW. maka diturunkanlah ayat ini (Quraish Shihab, 2000).

Bagi mereka dalam hal memasuki rumah dari belakang di anggap termasuk amal kabaikan yang hakiki, padahal apa yang mereka lakukan itu merupakan suatu kesalahan. Kebaikan yang hakiki adalah takwa kepada Allah dengan menjauhkan diri dari perbuatan-perbuatan maksiat dan kotor, serta menghiasi diri dengan keutamaankeutamaan, dan mengikuti kebenaran dan 
beramal kebaikan. Seperti halnya memasuki rumah dari depan, tidak dari belakang.

Beberapa riwayat mengatakan bahwa Nabi saw. pernah ditanya tentang bulan sabit itu, tentang penampakanya, perkembanganya, dan penyusutannya kembali, dan juga mengenai kegunaan diciptakannya bulan sabit. Yakni sebagai tanda- tanda waktu bagi manusia untuk bertahallul dan berihram, untuk berpuasa dan tidak berpuasa; untuk nikah, talak dan iddah; untuk mengadakan taransaksi- transaksi, perniagaan, utangpiutang; dan untuk urusan-urusan agama maupun urusan-urusan dunia.

\section{5). Isim Maerifat}

Kata waktu dalam bentuk isim makan disebutkan sebanyak 3 kali. Contohnya adalah kata Mīāti. Dilihat dari konteksnya, kata Mìāti bermakna waktu- waktu tertentu yang dikaitkan dengan ditetapkanya waktu, yakni tidak dapat dimajukan dan tidak dapat pula diundurkan, juga tidak dapat ditambahi serta tidak dapat dikurangi. berikut:

Contoh konteks ayatnya adalah sebagai

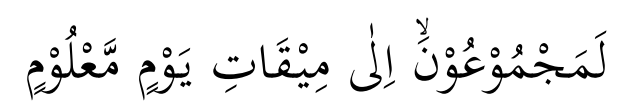

Pasti semua akan dikumpulkan pada waktu tertentu, pada hari yang sudah dimaklumi. (Q.S. Al-Wāqi'ah [56]: 50).

Kata miqat berarti alat untuk waktu, tetapi maknanya diperluas sehingga berarti waktu, atau tempat sesuatu (Quraish Shihab, 2000). Sedangkan menurut al-Maragi kata miqat diartiakan saat yang ditentukan untuk sesuatu. Maksudnya adalah hari kiamat, karena hari itulah saat penentuan penghabisan dunia. Bahwa orang-orang terdahulu yang menganggap tidak mungkin orang yang sudah meninggal akan dibangkitkan kembali. Mereka benar-benar akan dibangkitkan disatu tanah lapang pada hari yang ditentukan itu, dan tidak diragukan bahwa dikumpulkannya bilangan manusia yang tiada terhingga banyaknya, dan lebih mengherankan lagi dari pada kebagkitan itu sendiri. Semua yang telah mati dibangkitkan kembali untuk memulai kehidupan yang kedua. Tubuh yang rusak menjadi tulang belulang akan dikembalikanNya seperti sedia kala. Mereka dikumpulkan pada satu padang terbuka yang lazimnya di sebut padang mahsyar. Pada saat itu akan ada kejadian- kejadian yang sangat menakutkan yang dimaksudkan agar manusia bisa mengambil pelajaran dari hal tersebut. (Abdurrahman Habanakah, 1998).

\section{6). Isim Domir (Domir Munfasil)}

Kata waktu dalam bentuk isim domir disebutkan 1 kali. Contohnya adalah kata Mīqātuhum. Dilihat dari konteksnya, kata Mīqātuhum bermakna waktu mereka yang dikaitkan dengan hari pengadilan antara orang yang berbuat kebenaran dan orang yang berbuat kebatilan adalah waktu yang sudah dijanjikan untuk mereka semua.

Contoh konteks ayatnya adalah sebagai berikut:

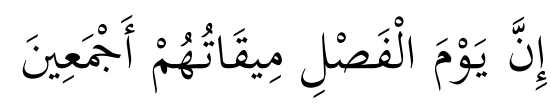

Sungguh, hari keputusan (hari kiamat) adalah waktu yang dijanjikan bagi mereka semuanya.(Q.S. Ad-Dukhān [44]: 40).

Ayat ini menjelaskan adanya hari pembalasan bagi siapa yang taat dan siapa yang membangkang (Quraish Shihab, 2000). Maka siapa saja yang berlaku baik dengan beriman kepada Allah, menaatinya, serta berlaku istiqamah dalam menjalankan syariatNya di dunia, pasti Allah menyediakan untuknya di alam akhirat kebahagiaan yang kekal dan kenikmatan yang tiada henti. Sebaliknya, siapa saja yang berlaku kafir dan maksiat kepada Allah, maka disediakan baginya diakhirat hukuman dan pembalasan yang setimpal dengan penuh keadilan.(Abdurrahman Habanakah, 1998). Atau bisa dinamakan hari keputusan, nasib bahagia masuk surga atau nasib celaka yang masuk neraka, dan juga membenarkan yang benar dan membatalkan yang batil. Mereka mendapat balasan atas apa yang telah mereka perbuat, tanpa dapat dibantu oleh seseorang, dan tidak dikasihi seseorang, kecuali orang yang mendapat rahmat Allah Rabb yang maha perkasa lagi maha penyayang. Yaitu, yang keluar dari tangan-Nya untuk bekerja, dan kembali ketangan-Nya untuk mendapatkan 
balasan dari-Nya. Dan, diantara keluarnya mereka serta kembalinya mereka itu adalah waktu untuk bekerja dan mendapatkan cobaan.

\section{7). Kata kerja waktu lampau ( $f$ 'il Mãdi)}

Kata waktu dalam bentuk fi'il Mādi disebutkan sebanyak 1 kali. Contohnya adalah kata uqqitat. (Quraish Shihab, 2000) Dilihat dari konteksnya, kata uqqitat bermakna waktu mereka yang dikaitkan dengan dikumpulkanya manusia pada hari kiamat. berikut:

Contoh konteks ayatnya adalah sebagai

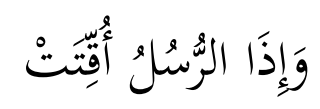

Dan apabila rasul-rasul telah ditetapkan waktunya.(QS. Al-Mursalat; [77]: 11).

Ayat di atas menjelaskan apa yang akan terjadi sebelum jatuhnya siksa yang dijanjikan itu. Kata uqqitat terambil dari kata waqt yang bermakna masa yang berlangsung dan berakhirnya suatu pekerjaan. Jika berbicara waktu shalat Zhuhur, maka itu berarti pada masa yang dimaksud shalat zhuhur telah dilakukan dan sudah harus selesai paling lambat dengan berakhirnya masa itu.

Berbeda pendapat ulama tentang waktu bagi rasul yang dimaksud. Di samping makna di atas, ada juga yang memahaminya dalam arti waktu dikumpulkannya para rasul itu. Ada lagi yang memahami kata tersebut dalam arti "batas akhir", yakni batas akhir yang diberikan kepada para rasul itu dan yangmereka tunggu-tunggu guna terbuktinya apa yang mereka sampaikan, yakni hari Kiamat.

Surah ini juga memaparkan urusan besar lainya yang ditangguhkan waktunya hingga hari kiamat.Yaitu, dijanjikanya kepada para rasul untuk melihat hasil dakwah kepada agama Allah sewaktu di dunia sepanjang masa.Para rasul telah ditentukan waktunya pada hari itu.Disanalah janji tersebut direalisasikan untuk melakukan perhitungan terakhir tentang urusan besar yang mengalahkan langit, bumi, gunung. Juga untuk memutuskan semua persoalan yang berhubungan dengan kehidupan di bumi (dunia) dan keputusan Allah padanya untuk mengumumkan kalimat terakhir yang merupakan kesudahan semua generasi dan angkatan.

\section{Bentuk-bentuk Pengungkapan Waktu Dalam al-Qur'an}

Dari uraian di atas, maka dapat dianalisis bahwa: Pembahasan tentang waktu setidaknya memiliki empat makna yang terkandung didalamnya: pertama, seluruh rangkaian saat yang telah lalu, sekarang dan yang akan datang. Kedua, saat tertentu untuk menyelesaikan sesuatu. Ketiga, kesempatan, tempo atau peluang. Keempat, ketika atau saat terjadinya sesuatu. Al-Qura'n menggunakan beberapa kata untuk menunjukkan makna tersebut, seperti: (1). Seluruh rangkaian saat yang telah lalu, sekarang dan yang akan datang, yang ditunjukkan dengan kata ghadah, ,ashr, bukrah, ashi>la>, ,asyiyya ${ }^{\text {ee }}$ isya $^{\text {ee }}$, layl, nahar, yawm, syahr, ,am, sanah. (2). Saat tertentu untuk menyelesaikan sesuatu dan (3). Kesempatan, tempo atau peluang yang ditunjukkan dengan kata waqt. Karena waqt digunakan dalam arti batas kesempatan atau peluang untuk menyelesaikan suatu aktifitas. Arti ini tercermin dari waktu-waktu shalat yang memberi kesan tentang keharusan adanya pembagian teknis mengenai masa yang di alami seperti detik, menit, jam, hari, minggu, bulan, tahun dan seterusnya dan sekaligus keharusan untuk menyelesaikan pekerjaan dalam waktu-waktu tersebut dan bukanya membiarkanya berlalu hampa. (4). Ketika atau saat terjadinya sesuatu yang ditunjukkan dengan kata dahr, ajal, hin dan sa ${ }^{e e} a h$.

\section{Manfaat Waktu Menurut Al-Qur'an}

Setiap Muslim harus memanfaatkan waktu yang dimilikinya dengan berbagai amal dengan mempergunakan semua daya yang di milikinya. Tidak boleh baginya untuk menyia-nyiakan waktunya hanya untuk bersenang-senang, bermain tanpa tujuan tertentu seperti kanak-kanak. Atau hanya sekedar mengisinya dengan bersolek seperti wanita dan juga menumpuk banyak harta serta berbangga-bangga memperbanyak anak. Setiap yang dilakukannya tidak akan ada yang luput dari pengawasanNya. Waktu harus diisi 
dengan kebaikan serta menjauh dari kedurhakaan. Oleh karena itu rasulullah Saw. memerintahkan umatnya agar memanfaatkan waktu yang tersisa dalam lima hal yaitu, masa muda sebelum datang masa tua, masa sehat sebelum datang masa sakit, waktu kaya sebelum datang waktu miskin, waktu luang sebelum datang waktu sibuk, dan waktu hidup sebelum datang ajal.

\section{PENUTUP}

Simpulan akhir dari pembahasan ini bahwa dalam ajaran Islam, Allah memerintahkan hamba-Nya untu memanfaatkan waktu dengan sebaik-baiknya, karena waktu merupakan hal yang sangat urgen sehingga memanfaatkan waktu merupakan amanat Allah kepada makhlukNya. Karena demikian urgenya peranan waktu, maka Allah berkali-kali bersumpah dengan menggunakan kata yang menunjukkan waktu-waktu tertentu. Al-Qur"an juga menggunakan term yang menunjukkan waktu yang berbeda-beda. Didalam al-Qur'an pengungkapan waktu terdapat dua bentuk, yaitu term yang menunjukkan durasi yang jelas batasanya seperti ghada' $h$, 'ashr, bukrah, ashi'la, 'asyiyya', 'isya', layl, naha'r, yawm, syahr, 'am, sanah.sedangkan term yang menunjukkan durasi yang tidak jelas batasanya seperti waqt, dahr, ajal, hin dan $\mathrm{sa}^{\mathrm{ee}}$ ah. Term yang menunjukkan durasi yang jelas batasanya berisi tentang waktu-waktu tertentu atau momentum kebajikan, waktu untuk beribadah dan juga menunjukkan perjalanan waktu atau perputaran matahari dan bulan dimana semua kejadian tersebut dapat dikatahui oleh manusia. Sedangkan term yang menunjukkan durasi yang tidak jelas batasanya berisi tentang keniscayaan, kebangkitan, penguasaan ruh dan maut, penentuan kematian, dan kebangkitan dan hari kiamat dimana hal tersebut tidak dapat diketahui oleh siapapun, seperti dahr digunakan untuk saat berkepanjangan yang dilalui alam raya dalam kehidupan dunia ini yaitu sejak diciptakan-Nya sampai punahnya alam, ajal menunjukkan waktu berakhirnya sesuatu seperti berakhirnya usia manusia, $\mathrm{sa}^{\text {ee } a h}$ menunjukkan akhir masa kehidupan duniawi serta kepunahan alam dan lain-lain.

\section{DAFTAR PUSTAKA}

Abdul Ba'qi, M. Fuad. Mu'jam al-Mufahras li al-Faz al-Quran al-Kari'm. Beirut: Dar al-Fikr, 1991

Abdurrahman Habanakah, Pokok-pukok Aqidah Islam, Jakarta: Gema Insani Press, 1998.

Ahmad Mustafa Al-Maragi, Tafsir Al-Maragi, Semarang: Cv Toha Putra, 1989.

Ahmad Warson Munawwir, Al-Munawwir: Kamus Arab Indonesia, Surabaya: Pustaka Progresif, 1997

Ahmad Warson Munawwir, Al-Munawwir: Kamus Arab Indonesia, Surabaya: Pustaka Progresif, 1997.

Ali Hasan, Setan Musuh Manusia Turuntemurun, Jakarta: Prenada Media, 2003

Fahmi Idris, Nilai dan Makna Kerja dalam Islam (Jakarta: Nuansa Madani, 1999), h.153.

M. Quraish Shihab, Wawasan al-Qur"ān, Tafsir Maudhu" $i$ atas Pelbagai Persoalan Umat, Bandung: Mizan, 2000.

M. Fuad Abdul Baqi, Mu'jam al-Mufahras li al-Faz al-Quran al-Karim Beirut: Dar al-Fikr, 1991.

Qutb, Sayyid. Tafsir Fi Zila al-Qurean: Di Bawah Naungan Al-Qurean, ter. As ${ }^{\text {ee }}$ ad Yasin. Jakarta: Gema Insani, 2000.

Shauqi Daif, Al-Mu jam Al-Wasit, Mesir: Maktabah Surouq al- Dauliyyah. 2011.

Shihab, M. Quraish. Tafsir Al-Misbah. Jakarta: lentera hati, 2000.

Shihab, M. Quraish. Wawasan al-Qur"ān, Tafsir Maudhu"i atas Pelbagai Persoalan Umat. Bandung: Mizan, 2000.

Yusuf Al-Qardhawi, "al-Waqtu fi Hayati alMuslim", ter. Ali Imron, Waktu Adalah Kehidupan, Yogyakarta: Mardhiyah Press, 2005 